\title{
Monitoring of essential and toxic elements in multi-ingredient food supplements produced in European Union
}

\author{
Barbara Poniedziałek ${ }^{1}$ Przemysław Niedzielski ${ }^{2} \cdot$ Lidia Kozak $^{3} \cdot$ Paweł Rzymski $^{4} \cdot$ Marcin Wachelka $^{2}$. \\ Izabela Rzymska ${ }^{5} \cdot$ Jacek Karczewski ${ }^{1} \cdot$ Piotr Rzymski ${ }^{1}$
}

Received: 19 June 2017 / Accepted: 3 January 2018 / Published online: 19 January 2018

(C) The Author(s) 2018. This article is an open access publication

\begin{abstract}
The market of food supplements (FS) in European Union (EU) is on the rise. The present study investigated the content of essential $(\mathrm{Ca}, \mathrm{Co}, \mathrm{Cr}, \mathrm{Cu}, \mathrm{Fe}, \mathrm{K}, \mathrm{Mg}, \mathrm{Mn}, \mathrm{Na}, \mathrm{Zn})$ and toxic elements $(\mathrm{Cd}, \mathrm{Cr}(\mathrm{VI})$, Ni and $\mathrm{Pb})$ in $168 \mathrm{FS}$ produced in the EU and designed to support various health aspects (nutrition, neurological function, reproduction, weight loss, cosmetic appearance). The majority of FS did not exceed a dissolution time of $60 \mathrm{~min}$ in hydrochloric acid (89.8\%) and phosphate buffer (85.7\%). $\mathrm{Cd}$ and $\mathrm{Cr}(\mathrm{VI})$ were not detected in any $\mathrm{FS}, \mathrm{Ni}$ and $\mathrm{Pb}$ were present sporadically (in 10.1 and $6.5 \%$, respectively) at mean concentrations of 0.06 and $0.07 \mathrm{mg} /$ single unit dose, respectively. All FS containing detectable $\mathrm{Pb}$ levels had exceeded a maximum allowance level $\left(3.0 \mathrm{mg} \mathrm{kg}^{-1}\right)$ set by the European Commission. Generally, the determined concentrations of essential elements fall greatly below recommended safety upper limits, except Fe in selected FS (mainly for pregnant women). Compared to the value declared on the product label, the majority of tested FS displayed mineral content below the accepted margin (70-130\%). In general, the majority of the studied FS can be considered safe although discrepancies between declared and determined mineral content are worrisome. These findings are important in view of FS consumer safety.
\end{abstract}

Keywords Food supplements · Mineral content $\cdot$ Contamination $\cdot$ Product safety

Piotr Rzymski

rzymskipiotr@ump.edu.pl

1 Department of Environmental Medicine, Faculty of Health Sciences, Poznan University of Medical Sciences, Poznan, Poland

2 Department of Analytical Chemistry, Faculty of Chemistry, Adam Mickiewicz University, Poznan, Poland

3 Department of Food, Nutrition and Food Contact Materials, Poviat Sanitary and Epidemiological Station in Poznań, Poznan, Poland

4 Department of Mother's and Child's Health, Gynecologic and Obstetrical University Hospital, Poznan University of Medical Sciences, Poznan, Poland

5 Department of Social Sciences, Faculty of Health Sciences, Poznan University of Medical Sciences, Poznan, Poland

\section{Introduction}

In recent years the global market for food supplements (FS) has shown a marked tendency to rise. As estimated, nearly $50 \%$ of the population in the United States and Japan use these products on daily basis (Hirayama et al. 2008; Bailey et al. 2013). Their popularity in Europe is also recently increasing with the highest consumption typical in northern countries (Reinert et al. 2007; Skeie et al. 2009). In member states of the European Union (EU) FS are classified as foodstuffs. Contrary to medical products, their registration requires no pre-clinical and clinical studies (Commission Directive 2002/46/EC novelized by Commission Regulation (EC) 1161/2011). However, they require labelling the products with certain particulars: (1) the names of the categories of nutrients or substances that characterise the product or an indication of the nature of those nutrients or substances; (2) the portion of the product recommended for daily consumption; (3) a warning not to exceed the stated recommended daily dose; (4) a statement 
to the effect that FS should not be used as a substitute for a varied diet and (5) a statement to the effect that the products should be stored out of the reach of young children (Directive 2002/46/EC). FS are made available without prescription or limitation not only in pharmacies but also in grocery shops, supermarkets, petrol stations, and at various online shops. Importantly, some of these products are currently used not only to improve nutritional status per se but also promoted for their therapeutic properties (Rzymski et al. 2016; Krasińska et al. 2017). A number of FS are targeted to support weight loss, reproduction, neurological function or attractive appearance (Chiba et al. 2015). However, such "health claims" are strictly regulated in the EU and all of them must be approved by European Food Safety Authority (EFSA). Disease-related claims are also forbidden by the food information regulation 1169/2011 (Regulation (EU) No 1169/2011). Nevertheless, a relatively significant part of food supplement users may still consider them as pharmaceuticals or as an alternative for disease treatment.

Recent concerns have been raised as to the quality and safety of selected FS following reports of their contamination or the presence of substances whose distribution is strictly regulated. For example, some microalgae-based products were found to cause significant side effects, exert cytotoxic effects in human cells, and were contaminated with significant levels of lead, aluminium (Rzymski et al. 2015a, 2017) or cyanotoxins (Heussner et al. 2012) while bodybuilding FS targeted at sportsman contained prohibited stimulant compounds (Geyer et al. 2008) or anabolic androgenic steroids (Abbate et al. 2015). Moreover, as found for selenium FS distributed in Poland, the declared nutritional values often differed significantly from actual content (Niedzielski et al. 2016).

Consumers of FS do not always consult physicians with regard to their intake (Chiba et al. 2015; Rzymski and Jaśkiewicz 2017). Such behaviour may lead to significant adverse health effects resulting from: (1) excessive consumption of minerals and/or vitamins; (2) supplementation of compounds inadequate for the consumer (e.g. due to specific disorder); (3) interactions of food supplement ingredients with medicines if the latter are concomitantly used. At the same time, producers often fail to include any information on a recommended daily dose of the manufactured supplement which is a clear infringement of EU law and indicates local problems with an enforcement problem (Niedzielski et al. 2016). Importantly, studies have shown that some physicians may be unaware of the biological properties of FS (Kemper et al. 2006; Ashar et al. 2007) while consumers may mistakenly consider these products as drugs designed to treat diseases (Wierzejska et al. 2014).
On balance it would seem that the enforcement of EUregulations concerning $\mathrm{FS}$ appear insufficient to fully protect consumer health in some countries. There have been reports of clinically-relevant hepatotoxic effects, adverse cardiac responses or even sudden death following the use of selected formulations marketed as FS (Geller et al. 2015; Rao et al. 2017). Therefore there is a continuous need to screen the quality of these products to ensure that they do not contain significant levels of toxic compounds or that the actual content of nutritional ingredients is not high enough to exceed tolerable daily doses through the consumption of a FS.

The present study aimed to investigate the essential element content in 168 multi-ingredient FS produced in the EU, registered and distributed in Poland following the dissolution preparation, to evaluate the contribution of a single dose at tolerable/safe intake levels, and to compare the determined mineral content to that declared on the product label. Additionally, FS were screened for the presence of widespread environmental pollutants harmful to human health - cadmium, nickel, lead and hexavalent form of chromium. The results of this study represent an important source of information on the quality and safety of FS of EU-origin.

\section{Materials and methods}

\subsection{Instrumentation and reagents}

A nitrogen microwave (with online nitrogen generator) induced plasma optical emission spectrometer (MIP-OES) MP-AED 4100 (Agilent, USA), with SPS-3 autosampler (Agilent, Australia), working in multi-elemental mode was used. As a reference analytical instrument, a flame (airacetylene) atomic absorption spectrometry SpectrAA 240FS (Varian, Australia) equipped with the SIPS-20 automatic system for standard solution preparation and online sample dilution (Varian, Australia) was applied in fastsequential multielemental mode. The UV-Vis spectrophotometer (Shimadzu, Japan) was used for spectrophotometric analyses. Detailed instrument parameters of analytical methods have been described previously (Niedzielski et al. 2014).

Only reagents of analytical purity and deionised water produced in a Milli-Q device (Millipore, USA) were used. For MIP-OES analysis the multi-elemental commercial analytical standard (Merck, Germany) and for FAAS analysis the AAS commercial standards (Merck, Germany) were applied. Hydrochloric acid (30\%) and nitric acid (65\%) (Merck, Germany) were used for sample preparation. The buffer was prepared by mixing disodium hydrophosphate $\left(\mathrm{Na}_{2} \mathrm{HPO}_{4}\right)$ and potassium dihydrophosphate 
$\left(\mathrm{KH}_{2} \mathrm{PO}_{4} \cdot 2 \mathrm{H}_{2} \mathrm{O}\right)$ obtained from Merck, Germany. For analysis quality control the standard reference materials BCR667 (JRC's Institute for Reference Materials and Measurements, European Commission), NIST2709 (National Institute of Standards and Technology, USA) and IAEA405 (International Atomic Energy Agency, Austria) were adopted (Niedzielski et al. 2014).

\subsection{Food supplements}

A total of 168 multi-ingredient FS were purchased in registered pharmacies in Poland. The inclusion criteria were: production in European Union, tablet form, and calcium $(\mathrm{Ca})$, chromium $(\mathrm{Cr})$, copper $(\mathrm{Cu})$, iron $(\mathrm{Fe})$, magnesium $(\mathrm{Mg})$, manganese $(\mathrm{Mn})$ and zinc $(\mathrm{Zn})$ declared as an ingredient on the label. The mean declared content in the single unit dose was $89.1 \pm 112.2 \mathrm{mg}$ (range 2-720 mg) for $\mathrm{Ca}, 0.8 \pm 0.4 \mathrm{mg}$ (range $0.15-2.0 \mathrm{mg}$ ) for $\mathrm{Cu}, 0.1 \pm 0.2 \mathrm{mg}$ (range 0.01-1.0) for $\mathrm{Cr}, 61.5 \pm 63.2 \mathrm{mg}$ (range 5-400 mg) for $\mathrm{Mg}, \quad 1.4 \pm 0.8 \mathrm{mg}$ (range $0.17-5.0 \mathrm{mg}$ ) for $\mathrm{Mn}, \quad 11.8 \pm 16.4 \mathrm{mg} \quad$ (range $1.0-100.0 \mathrm{mg}$ ) for $\mathrm{Fe}$ and $8.6 \pm 3.9 \mathrm{mg}$ (range $0.05-20.0 \mathrm{mg}$ ) for $\mathrm{Zn}$. The analyzed products also contained other ingredients including vitamin A (35.1\%), vitamin B1 (41.7\%), vitamin B2 (41.1\%), vitamin B5 (37.5\%), vitamin B6 (48.8\%), vitamin B7 (38.1\%), vitamin B9 $(45.2 \%)$, vitamin B12 (47.0\%), vitamin D3 (34.0\%) vitamin $\mathrm{E}(51.2 \%)$, vitamin $\mathrm{K}(11.9 \%)$, vitamin $\mathrm{PP}$ $(36.9 \%)$, L-glutathione $(2.4 \%)$, L-cysteine $(3.6 \%)$, L-carnitine $(0.6 \%)$, L-methionine $(2.4 \%)$, L-lysine $(0.6 \%)$, coenzyme Q10 (2.4\%), lutein $(13.1 \%)$, taurine $(0.6 \%)$, lecithin $(1.2 \%)$, caffeine $(0.6 \%)$, hyaluronic acid $(1.2 \%)$, iodine $(23.2 \%)$, molybdenum $(10.1 \%)$, selenium $(50.6 \%)$. Based on information given by the manufacturer on the product label, the supplements were further divided into the following groups on the basis of label description: (1) supporting general nutrition ( $\mathrm{n}=81)$, (2) supporting neurological function $(\mathrm{n}=18)$, (3) supporting reproduction $(\mathrm{n}=24)$, (4) supporting weight loss $(\mathrm{n}=22)$, and (5) supporting cosmetic appearance $(n=23)$.

\subsection{Solubility and dissolution assays}

The study was performed for a single unit dose of the preparation standardized for a table size. Tablets of each preparation were weighed. Solutions for extraction of trace elements were chosen so that they would imitate conditions in the alimentary system. The stage of dissolving in the stomach was mimicked with the use of hydrochloric acid, while the conditions of absorption in the intestines were reproduced with the use of a phosphate buffer. One tablet of each preparation was dissolved in $25 \mathrm{~mL}$ of $\mathrm{HCl}$ with a concentration of $100 \mathrm{mmol} \mathrm{L}^{-1}$, another one in $25 \mathrm{~mL}$ of phosphate buffer solution of $\mathrm{pH} 6.0$, containing $10 \mathrm{mmol}$ $\mathrm{L}^{-1}$ of $\mathrm{Na}_{2} \mathrm{HPO}_{4}$ and $45 \mathrm{mmol} \mathrm{L}^{-1}$ of $\mathrm{KH}_{2} \mathrm{PO}_{4}$. The tablets were dissolved under the condition of thermostatting the samples at $37{ }^{\circ} \mathrm{C}$, using a magnetic mixer. For each preparation, the extraction was repeated three times. The total dissolution time in $\mathrm{HCl}$ and buffer was recorded. If a preparation was not fully dissolved, the undissolved mass was determined (European Pharmacopoeia 2011).

\subsection{Trace element analysis}

The hydrochloric acid extracts were filtered and subjected to mineralization with nitric acid. A portion of $5 \mathrm{~mL}$ of the extract was supplemented with $15 \mathrm{~mL}$ of nitric acid and the mixture was heated under reflux up to approximately $90{ }^{\circ} \mathrm{C}$ for $2 \mathrm{~h}$. The mixtures were filtered off and the filtrate was subjected to determination of the total content of declared ingredients: $\mathrm{Ca}, \mathrm{Cr}, \mathrm{Cu}, \mathrm{Fe}, \mathrm{Mg}, \mathrm{Mn}$ and $\mathrm{Zn}$. Moreover, total levels of cobalt $(\mathrm{Co})$, sodium $(\mathrm{Na})$ and potassium (K) were also analysed. Majority of studied FS also contained vitamin B12, a Co-containing corrinoid. Excessive intake of $\mathrm{Na}$ and decreased consumption of $\mathrm{K}$ have been associated with an increased risk of cardiovascular disease and all-cause mortality (Yang et al. 2011). Yet, the contribution of multi-ingredient FS to their intake remains mostly unknown (Rhodes et al. 2013). Contamination of studied products was evaluated by determining content of three toxic metals: cadmium (Cd), nickel (Ni) and lead $(\mathrm{Pb})$. All of these analyses were performed using atomic absorption and atomic emission spectrometric techniques. Additionally, hexavalent $\mathrm{Cr}$ form, $\mathrm{Cr}(\mathrm{VI})$, was determined using the colorimetric method with diphenylcarbazyd. The eventual presence of a red-coloured complex of $\mathrm{Cr}(\mathrm{VI})$ was determined at $540 \mathrm{~nm}$.

\subsection{Calculations}

The results were analyzed using STATISTICA 10.0 software (StatSoft, USA). Because the data met the assumption on Gaussian distribution (analyzed with the Shapiro-Wilk test) and compared groups were unequal, non-parametric methods were employed. Dissolution time and solubility in hydrochloric acid and phosphate buffer was analyzed with the Wilcoxon signed-rank test. Correlation time between dissolution time in both solutions was evaluated with Spearman's rank correlation coefficient. In all analyses, $\mathrm{p}<0.05$ was considered as statistically significant. Determined levels of essential elements per single dose unit were compared to Safety Upper Levels (SULs) or Guideline Levels (GLs) for daily intake based on recommendations set by The Expert Group on Vitamins and Minerals (EVM 2003). The following values were used: $\mathrm{Ca}$ $1500 \mathrm{mg}, \mathrm{Cu} 10 \mathrm{mg}$, Co $1.4 \mathrm{mg}, \mathrm{Cr} 10 \mathrm{mg}, \mathrm{Fe} 17 \mathrm{mg}, \mathrm{K}$ 
$3700 \mathrm{mg}, \mathrm{Mg} 400 \mathrm{mg}$, Mn 4 mg, Na (not set), Zn 25 mg (EVM 2003). In the case of toxic metals, their content was expressed as a percentage of the Provisional Tolerable Weekly Intake (PTWI) set by JECFA (2000) for $\mathrm{Pb}$ $\left(0.025 \mathrm{mg} \mathrm{kg} \mathrm{bw}^{-1}\right)$ and the Tolerable Daily Intake (TDI) set by EFSA (2015) for $\mathrm{Ni}\left(0.0028 \mathrm{mg} \mathrm{bw}^{-1}\right)$ calculated for an average $70 \mathrm{~kg}$ adult. Moreover, the content of $\mathrm{Cd}$ and $\mathrm{Pb}$ was confronted with maximum allowance levels set for FS by European Commission 1.0 and $3.0 \mathrm{mg} \mathrm{kg}^{-1}$, respectively (Regulation (EC) No 629/2008: amending Regulation (EC) No 1881/2006). The content of minerals $(\mathrm{Ca}, \mathrm{Cr}, \mathrm{Cu}, \mathrm{Fe}, \mathrm{Mg}, \mathrm{Mn}$ and $\mathrm{Zn}$ ) determined after acidic dissolution was confronted with a content declared on the label, and $70-130 \%$ of declared value was considered as an acceptable margin (Niedzielski et al. 2014).

\section{Results}

\subsection{Dissolution tests}

Only 17 studied supplements (10.2\%) were characterized by a dissolution time in hydrochloric acid longer than 60 min. The mean \pm SD time of all tested formulas was $29.6 \pm 33.2 \mathrm{~min}$ and no significant differences were noted between particular groups of FS (Fig. 1a). In turn, the dissolution time of $24(14.3 \%)$ products in phosphate buffer exceeded 60 min with a mean $\pm S D$ time of $36.6 \pm 38.5 \mathrm{~min}$ found for all tested FS. No significant differences were noted between the tested groups (Fig. 1a). Dissolution times recorded in both solutions were not significantly different from each other (based on the run tests) but, in turn, they were strongly correlated $(\mathrm{Rs}=0.85 ; \mathrm{p}<0.05)$.

The solubility of analyzed FS in hydrochloric acid and phosphate buffer were significantly different (based on the run tests). The mean $\pm \mathrm{SD}$ of dissolved mass in acid and buffer was $63.0 \pm 21.3$ and $53.3 \pm 26.6 \%$, respectively. Only $26(15.5 \%)$ and $10(6.0 \%)$ formulas had solubility in acid and buffer, respectively exceeding 90\%. The lowest observed solubility in acid was $13.7 \%$ and in buffer $7.6 \%$. Although solubility in acids did not differ between particular supplement groups, the solubility of formulas presumably supporting weight loss, neurological function and cosmetic appearance in phosphate buffer was significantly lower compared to those designed to support general nutrition (Fig. 1b).

\subsection{Essential element content}

All 10 essential elements $(\mathrm{Ca}, \mathrm{Cr}, \mathrm{Co}, \mathrm{Cu}, \mathrm{Fe}, \mathrm{Mg}, \mathrm{Mn}, \mathrm{K}$, $\mathrm{Na}$ and $\mathrm{Zn}$ ) were identified in the tested FS. The SULs/GLs were exceeded sporadically, mainly for Fe. This mostly
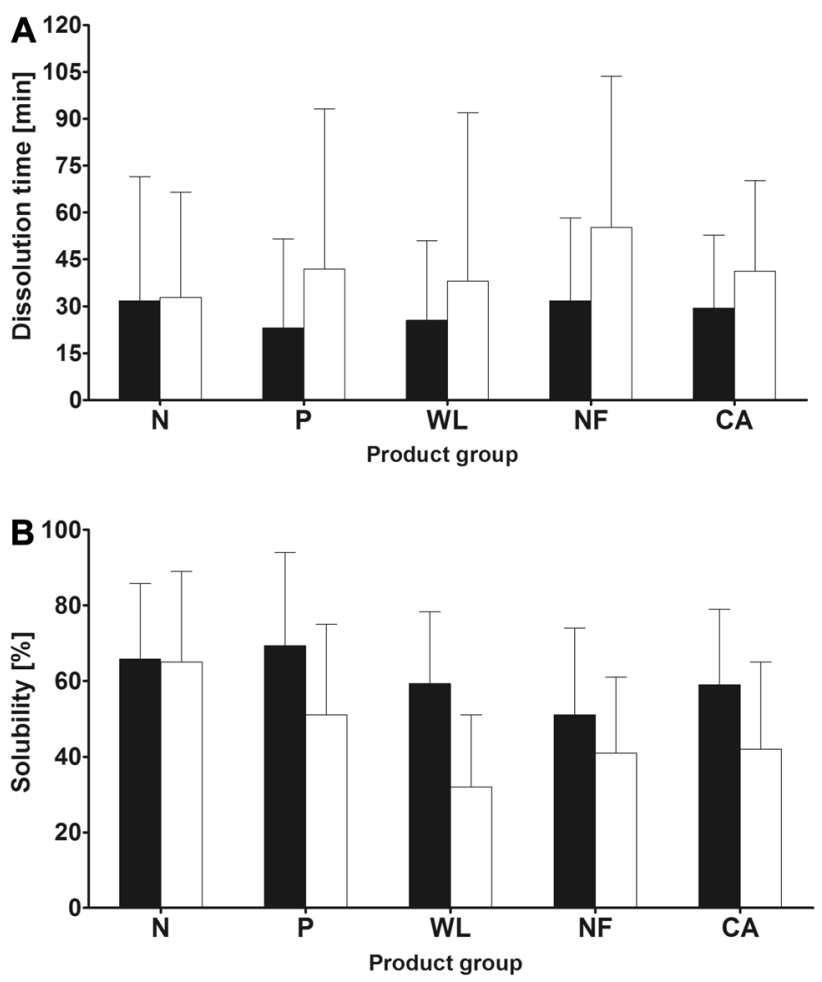

Fig. 1 The mean ( \pm SD) dissolution time (a) and solubility (b) of food supplements $(\mathrm{n}=168)$ in hydrochloric acid (white boxes) and phosphate buffer (black boxes) in relation to particular product groups: supplements aimed to support general nutrition $(\mathrm{N})$, pregnancy $(\mathrm{P})$, weight loss $(\mathrm{WL})$, neurological function $(\mathrm{NF})$ and cosmetic appearance (CA)

concerned pregnancy supporting supplements of which six had exceeded GL and one had exceeded it by over $240 \%$. (Table 1). Fe concentrations in a single dose unit above recommended levels were also found for three supplements aimed to support general nutrition (114-168\% of GL) and one supporting weight loss (166\% of GL). The comparison of determined mineral content after acidic dissolution to that declared on the product label is presented on Fig. 2. The majority of FS displayed mineral content below an acceptable margin of the declared value (70-130\%). In case of $\mathrm{Ca}, \mathrm{Cr}, \mathrm{Cu}, \mathrm{Mg}, \mathrm{Mn}, \mathrm{Fe}$ and $\mathrm{Zn}$ this issue concerned 88.1, 55.2, 55.3, 83.0, 69.7, 68.5 and $67.9 \%$, of tested FS, respectively. The greatest percentage of FS falling within an acceptable margin was noted for $\mathrm{Cu}(36.2 \%$ of FS), $\mathrm{Mn}$ (27.3\% of FS) and $\mathrm{Zn}$ (23.1\% of FS). It should also be noted that in relatively high frequency of FS, the content exceeding an acceptable margin was found relatively often for $\mathrm{Cr}(26.0 \% \mathrm{FS})$ and $\mathrm{Fe}(12.5 \%$ of FS) with 16.5 and $6.6 \%$ of FS exceeding it by as much as over $200 \%$, respectively (Fig. 2). 
Table 1 Levels of essential metals in food supplements $(n=168)$ in relation to the safe upper intake level (SUL) or guideline level (GL)

\begin{tabular}{lllll}
\hline & $\begin{array}{l}\text { Mean/maximum (mg per } \\
\text { single dose unit) }\end{array}$ & $\begin{array}{l}\text { Mean/maximum } \% \\
\text { of SUL/GL }\end{array}$ & $\begin{array}{l}\%(\mathrm{n}) \text { of supplements } \\
\text { constituting }>50 \% \text { of SUL/GL }\end{array}$ & $\begin{array}{l}\text { \% (n) of supplements } \\
\text { exceeding SUL/GL }\end{array}$ \\
\hline $\mathrm{Ca}$ & $29.1 / 529$ & $3.5 / 35.3$ & $0(0)$ & $0(0)$ \\
$\mathrm{Co}$ & $0.06 / 0.07$ & $4.3 / 5.0$ & $0(0)$ & $0(0)$ \\
$\mathrm{Cr}$ & $0.21 / 0.40$ & $2.1 / 4.0$ & $0(0)$ & $0(0)$ \\
$\mathrm{Cu}$ & $0.56 / 1.7$ & $5.6 / 17$ & $0(0)$ & $0(0)$ \\
$\mathrm{Fe}$ & $6.8 / 246$ & $40.0 / 1445$ & $13.7(23)$ & $6.0(10)$ \\
$\mathrm{K}$ & $16.5 / 174$ & $0.5 / 4.7$ & $0(0)$ & $0(0)$ \\
$\mathrm{Mg}$ & $11.3 / 171$ & $2.85 / 42.7$ & $0(0)$ & $0(0)$ \\
$\mathrm{Mn}$ & $0.73 / 5.5$ & $18.2 / 137$ & $4.2(7)$ & $0.6(1)$ \\
$\mathrm{Na}$ & $52.4 / 655$ & - & - & - \\
$\mathrm{Zn}$ & $4.9 / 27.8$ & $19.6 / 111$ & $1.8(3)$ & $0.6(1)$ \\
\hline
\end{tabular}

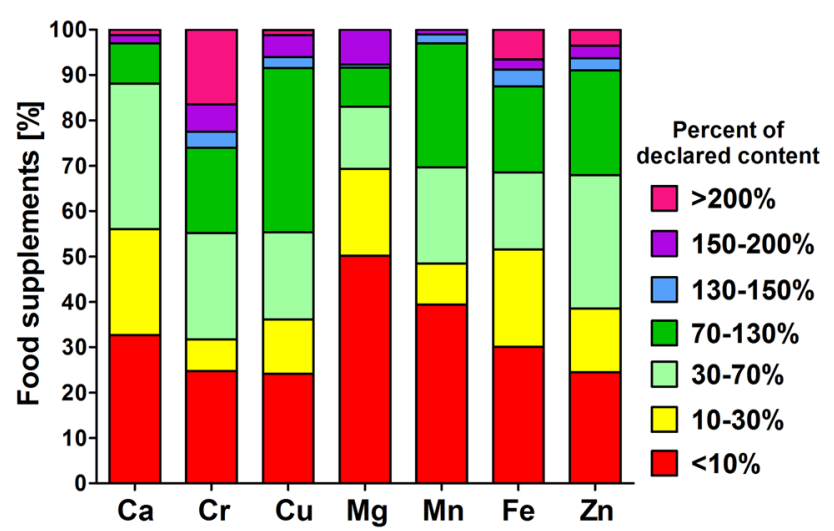

Fig. 2 The content of $\mathrm{Ca}, \mathrm{Cr}, \mathrm{Cu}, \mathrm{Fe}, \mathrm{Mg}, \mathrm{Mn}$ and $\mathrm{Zn}$ determined in food supplements after acidic dissolution $(\mathrm{n}=168)$ presented as a percentage of content declared on the label

\subsection{Toxic element content}

None of the analyzed FS had detectable levels of $\mathrm{Cd}$ and $\mathrm{Cr}(\mathrm{VI})$. In turn, $\mathrm{Ni}$ and $\mathrm{Pb}$ were present in $10.1 \%(17 / 168)$ and $6.5 \%(11 / 168)$ of $\mathrm{FS}$, respectively, at a mean $\pm \mathrm{SD}$ content of $0.06 \pm 0.01$ and $0.07 \pm 0.02 \mathrm{mg} / \mathrm{single}$ unit dose, respectively. In these cases, daily use of a single unit dose by a $70 \mathrm{~kg}$ adult would represent $30.6 \%$ of TWI for Ni and $28 \%$ of PTWI for $\mathrm{Pb}$. All FS that contained detectable levels of $\mathrm{Pb}$ had exceeded a maximum allowance level (3.0 $\left.\mathrm{mg} \mathrm{kg}^{-1}\right)$ set by the European Commission with two products exceeding it by as much as 11.1-fold and 16.9-fold (Fig. 3).

\section{Discussion}

The FS are becoming an important part of daily life and this trend is likely to retain its status quo or even to increase (Reinert et al. 2007; Dickinson et al. 2015).

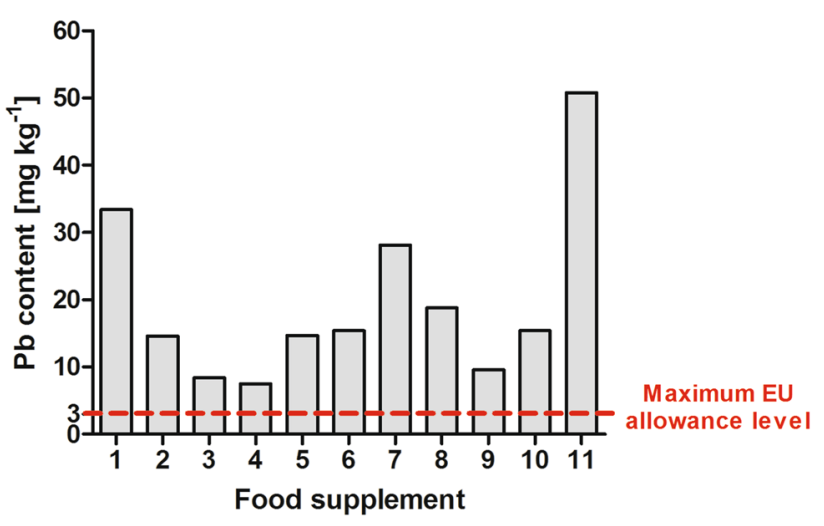

Fig. 3 The $\mathrm{Pb}$ content determined in 11 food supplements $(6.5 \%$ of all studied products) in relation to maximum EU allowance level

Favorable regulations in the EU allow these products to be easily introduced to the market and made widely available. It is beyond any doubt that an effort should be made to ensure their quality and safety for potential consumers through e.g. implementation of a food safety management system according to ISO 22000 and efficient enforcement of EU regulations in particular member states (FernándezSegovia et al. 2014). The FS available on the EU market are produced worldwide and some are manufactured by European companies. Although a number of reports have exposed the doubtful quality of selected FS produced outside the EU (Dolan et al. 2003; Rzymski et al. 2015a; Veprikova et al. 2015; Rao et al. 2017), there still remained a need to screen the European formulas. The present study is a comprehensive assessment of EU-manufactured multiingredient supplements based on minerals and vitamins sold in Polish pharmacies as regards their bioavailability, and levels of essential and toxic elements.

The bioavailability of multi-ingredient formulas may be a subject to various competitive interactions between trace elements resulting in decreased solubility and increased 
dissolution time (Yetley 2007). Some other compounds present in FS may increase the bioavailability of selected elements, e.g. ascorbic acid may enhance absorption of iron if it is present in an inorganic form (Hallberg et al. 1989). Our results show that most of the investigated FS were characterized by medium solubility in both acid and phosphate buffer but dissolution time generally falls below the limit of $60 \mathrm{~min}$. This highlights that compounds present in the analyzed FS may only be absorbed partially. However, it should be highlighted that the $\mathrm{pH}$ is only one condition that influences the bioavailability.

The investigated FS were multi-ingredient, contained various configurations of minerals and vitamins, and therefore differed in levels of essential elements. From the perspective of health protection, it is important to evaluate whether their concentrations do not exceed safety/guideline levels because an excessive intake can lead to various adverse effects including neurotoxic responses (Mn), cardiotoxicity (Co), gastrointestinal symptoms $(\mathrm{Cu}, \mathrm{Fe}, \mathrm{K}$, $\mathrm{Mg}$ ), altered immune function ( $\mathrm{Zn})$ or unwanted cardiovascular events (Ca) (Verkaik-Kloosterman et al. 2012). Generally, our study demonstrated that the multi-ingredient FS produced in the EU have essential element concentrations decidedly below upper safety limits. The significantly greater Fe content found in supplements aimed to support pregnancy compared to the other studied groups can be explained by the increased demand of this element in pregnant women due to excessive loss of blood and risk of anemia (Milman et al. 1999). In other cases, its increased intake can lead to Fe overloading associated with gastrointestinal distress (Frykman et al. 1994) and the generation of reactive oxygen species through Fenton and Haber-Weiß reactions and subsequent oxidative stress (Galaris and Pantopoulos 2008; Komosa et al. 2017). However, it should be highlighted that the significantly exceeded GL values of Fe in other investigated supplement groups were found sporadically.

The important and worrisome finding of the present study is the discrepancy observed between the mineral content determined after acidic dissolution and the value declared on label by FS producer. For majority of FS, the determined content of $\mathrm{Ca}, \mathrm{Cr}, \mathrm{Cu}, \mathrm{Mn}, \mathrm{Mg}, \mathrm{Fe}$ and $\mathrm{Zn}$ did not comply with acceptable margin (70-130\% of declared value). Previous studies have found that declared Se contents in FS from the EU market does not agree with its actual levels with just as little as $20 \%$ of investigated products meeting the acceptable margin (Niedzielski et al. 2016). Such discrepancies were also reported previously for content of coenzyme Q10 (Pravst and Žmitek 2011), folic acid, vitamin A, vitamin C (Brandon et al. 2014) and vitamin D (Verkaik-Kloosterman et al. 2017). As demonstrated by Gabriels and Lambert (2013), the nutritional value of the FS declared on container label is an important factor assisting the consumers' decision-making processes, when purchasing a product. The findings of both our study and previous investigations highlight that consumers may often be misleaded in this regard, and underline a potential need for more strict controls of credibility of label information. Toxic metals such as $\mathrm{Cd}, \mathrm{Pb}$ or $\mathrm{Ni}$ are one of the most common environmental pollutants which can enter food chains and be present at elevated levels in some foodstuffs (Singh et al. 2011; Rzymski et al. 2015b). Considering that investigated products are often used on a daily basis and some are also used by pregnant women, determination of their purity is of high interest as regards the protection of consumer health. Screening for toxic metals such as $\mathrm{Cd}, \mathrm{Pb}$ or $\mathrm{Ni}$ in $\mathrm{FS}$ was previously performed in Europe but on a much smaller scale and mainly for products containing herbs of Asian origin (Tumir et al. 2010; Filipiak-Szok et al. 2015; Rzymski et al. 2015a). Those studies reported that some biomass-based formulas may contain $\mathrm{Cr}, \mathrm{Pb}$ or $\mathrm{Ni}$ at levels potentially harmful to human health. Such contamination likely results from the presence of toxic metals, in the ambient environment (soil or water) and the subsequent bioaccumulation process (Rzymski et al. 2015b). The present study employed a larger group of FS and specifically aimed to investigate synthetic formulas produced within EU member states. In such case, metal contamination can most likely occur if the technological process of their production is carried out under uncontrolled conditions or the ingredients used in this process are not of the highest purity. As demonstrated, no product investigated in the present study was characterized by detectable levels of $\mathrm{Cd}$ contamination. In turn, a contamination with $\mathrm{Pb}$ or $\mathrm{Ni}$ was sporadically found, although at levels considerable enough to pose a potential health threat if the supplements are consumed on a daily basis. However, it should be noted that the PTWI value for $\mathrm{Pb}(25 \mu \mathrm{g} / \mathrm{kg}$ bw), to which the determined $\mathrm{Pb}$ concentrations were confronted, is no longer valid because it was considered as not sufficiently protective but no new value was established (JECFA 2011). None of analyzed products contained detectable levels of the $\mathrm{Cr}$ (VI) form known to act as a carcinogen (Sun et al. 2015). This is a very important finding if one considers a previous disquieting report of $\mathrm{Cr}(\mathrm{VI})$ constituting up to a $16 \%$ share in the total $\mathrm{Cr}$ quota in some FS available on the U.S. market (Martone et al. 2013).

In summary, the study evaluated the bioavailability, content of essential elements and toxic metal contamination in multi-ingredient FS produced in the EU and distributed in Polish pharmacies. Generally, these formulas were demonstrated to have medium availability under conditions designed to reproduce those of the stomach and intestines. The tested FS were found to contain essential elements and toxic metals below potentially harmful levels. 
In this regard, they can therefore be concerned as safe for consumers. Majority of tested FS displayed the mineral content much below the valued declared on label.

\section{Compliance with ethical standards}

Conflict of interest The authors declare that they have no conflict of interest.

Open Access This article is distributed under the terms of the Creative Commons Attribution 4.0 International License (http://creative commons.org/licenses/by/4.0/), which permits unrestricted use, distribution, and reproduction in any medium, provided you give appropriate credit to the original author(s) and the source, provide a link to the Creative Commons license, and indicate if changes were made.

\section{References}

Abbate V, Kicman AT, Evans-Brown M, McVeigh J, Cowan DA, Wilson C, Coles SJ, Walker CJ (2015) Anabolic steroids detected in bodybuilding food supplements - a significant risk to public health. Drug Test Anal 7:609-618

Ashar BH, Rice TN, Sisson SD (2007) Physicians' understanding of the regulation of food supplements. Arch Int Med 167:966-969

Bailey RL, Gahche JJ, Miller PE, Thomas PR, Dwyer JT (2013) Why US adults use food supplements. JAMA Intern Med 173:355-361

Brandon EF, Bakker MI, Kramer E, Bouwmeester H, Zuidema T, Alewijn M (2014) Bioaccessibility of vitamin A, vitamin C and folic acid from dietary supplements, fortified food and infant formula. Int J Food Sci Nutr 65:426-435

Chiba T, Sato Y, Suzuki S, Umegaki K (2015) Concomitant use of food supplements and medicines in patients due to miscommunication with physicians in Japan. Nutrients 7:2947-2960

Council of Europe, European Pharmacopoeia Commission \& European Directorate for the Quality of Medicines \& Healthcare (2010) European pharmacopoeia. Council Of Europe, Strasbourg

Dickinson A, MacKay D, Wong A (2015) Consumer attitudes about the role of multivitamins and other food supplements: report of a survey. Nutr J 14:66

Dolan SP, Nortrup DA, Bolger PM, Capar SG (2003) Analysis of food supplements for arsenic, cadmium, mercury, and lead using inductively coupled plasma mass spectrometry. J Agric Food Chem 51:1307-1312

European Food Safety Authority (2015) Scientific opinion on the risks to public health related to the presence of nickel in food and drinking water. EFSA J. https://doi.org/10.2903/j.efsa.2015.4002

Fernández-Segovia I, Pérez-Llácer A, Peidro B, Fuentes A (2014) Implementation of a food safety management system according to ISO 22000 in the food supplement industry: a case study. Food Control 43:28-34

Filipiak-Szok A, Kurzawa M, Szłyk E (2015) Determination of toxic metals by ICP-MS in Asiatic and European medicinal plants and food supplements. J Trace Elem Med Biol 230:54-58

Frykman E, Bystrom M, Jansson U, Edberg A, Hansen T (1994) Side effects of iron supplements in blood donors; superior tolerance of heme iron. J Lab Clin Med 123:561-564

Gabriels G, Lambert M (2013) Nutritional supplement products: does the label information influence purchasing decisions for the physically active? Nutr J 12:133
Galaris D, Pantopoulos K (2008) Oxidative stress and iron homeostasis: mechanistic and health aspects. Crit Rev Clin Lab Sci 45:1-23

Geller AI, Shehab N, Weidle NJ, Lovegrove MC, Wolpert BJ, Timbo BB, Mozersky RP, Budnitz DS (2015) Emergency department visits for adverse events related to food supplements. New Eng J Med 373:1531-4150

Geyer H, Parr MK, Koehler K, Mareck U, Schänzer W, Thevis M (2008) Nutritional supplements cross-contaminated and faked with doping substances. J Mass Spectrom 43:892-902

Hallberg L, Brune M, Rossander L (1989) The role of vitamin C in iron absorption. Int J Vitam Nutr Res Suppl 30:103-108

Heussner AH, Mazija L, Fastner J, Dietrich DR (2012) Toxin content and cytotoxicity of algal food supplements. Toxicol Appl Pharmacol 265:263-271

Hirayama F, Lee AH, Binns CW, Watanabe F, Ogawa T (2008) Food supplementation by older adults in Japan. Asia Pac J Clin Nutr $17: 280-284$

JECFA (2000) Evaluation of certain food additives and contaminants. Fifty-third report of the Joint FAO/WHO Expert Committee on Food Additives. WHO Technical Report Series: 896

JECFA (2011) Safety evaluation of certain contaminants in food/ prepared by the seventy-third meeting of the joint FAO/WHO Expert Committee on Food Additives (JECFA). WHO Food Additives Series: 64

Kemper KJ, Gardiner P, Gobble J, Woods C (2006) Expertise about herbs and food supplements among diverse health professionals. BMC Comp Alternat Med. https://doi.org/10.1186/1472-6882-615

Komosa A, Rzymski P, Perek B, Ropacka-Lesiak M, Lesiak M, Siller-Matula JM, Poniedziałek B (2017) Platelets redox balance assessment: current evidence and methodological considerations. Vascul Pharmacol 93-95:6-13

Krasińska B, Osińska A, Osińska M, Krasińska A, Rzymski P, Tykarski A, Krasiński Z (2017) Standardised tomato extract as an alternative to acetylsalicylic acid in patients with primary hypertension and high cardiovascular risk — a randomised, controlled trial. Arch Med Sci. https://doi.org/10.5114/aoms. 2017.69864

Martone N, Rahman GM, Pamuku M, Kingston HM (2013) Determination of chromium species in food supplements using speciated isotope dilution mass spectrometry with mass balance. J Agric Food Chem 61:9966-9976

Milman N, Bergholt T, Byg KE, Eriksen L, Graudal N (1999) Iron status and iron balance during pregnancy. A critical reappraisal of iron supplementation. Acta Obstet Gynecol Scand 78:749-757

Niedzielski P, Kozak L, Wachelka M, Jakubowski K, Wybieralska J (2014) The microwave induced plasma with optical emission spectrometry (MIP-OES) in 23 elements determination in geological samples. Talanta 132:591-599

Niedzielski P, Rudnicka M, Wachelka M, Kozak L, Rzany M, Wozniak M, Kaskow Z (2016) Selenium species in selenium fortified food supplements. Food Chem 190:454-459

Pravst I, Žmitek K (2011) The coenzyme Q10 content of food supplements. J Consumer Protect Saf 6:457-463

Rao N, Spiller HA, Hodges NL, Chounthirath T, Casavant MJ, Kamboj AK, Smith GA (2017) An increase in dietary supplement exposures reported to US Poison Control Centers. J Med Toxicol. https://doi.org/10.1007/s13181-017-0623-7

Reinert A, Rohrmann S, Becker N, Linseisen J (2007) Lifestyle and diet in people using food supplements. Eur J Nutr 46:165-173

Rhodes DG, Murayi T, Clemens JC, Baer DJ, Sebastian RS, Moshfegh AJ (2013) The USDA automated multiple-pass method accurately assesses population sodium intakes. Am J Clin Nutr 97:958-964 
Rzymski P, Jaśkiewicz M (2017) Microalgal food supplements from the perspective of Polish consumers: patterns of use, adverse events, and beneficial effects. J Appl Phycol 29:1841-1850

Rzymski P, Niedzielski P, Kaczmarek N, Jurczak T, Klimaszyk P (2015a) The multidisciplinary approach to safety and toxicity assessment of microalgae-based food supplements following clinical cases of poisoning. Harmful Algae 46:34-42

Rzymski P, Tomczyk K, Rzymski P, Poniedziałek P, Opala T, Wilczak M (2015b) Impact of heavy metals on the female reproductive system. Ann Agr Env Med 22:259-264

Rzymski P, Mleczek M, Niedzielski P, Siwulski M, Gąsecka M (2016) Potential of cultivated Ganoderma lucidum mushrooms for the production of supplements enriched with essential elements. J Food Sci. https://doi.org/10.1111/1750-3841

Singh R, Gautam N, Mishra A, Gupta R (2011) Heavy metals and living systems: an overview. Ind J Pharmacol 43:246-253

Skeie G, Braaten T, Hjartåker A, Lentjes M, Amiano P, Jakszyn P, Pala V, Palanca A, Niekerk EM, Verhagen H, Avloniti K, Psaltopoulou T, Niravong M, Touvier M, Nimptsch K, Haubrock J, Walker L, Spencer EA, Roswall N, Olsen A, Wallström P, Nilsson S, Casagrande C, Deharveng G, Hellström V, BoutronRuault MC, Tjønneland A, Joensen AM, Clavel-Chapelon F, Trichopoulou A, Martinez C, Rodríguez L, Frasca G, Sacerdote C, Peeters PH, Linseisen J, Schienkiewitz A, Welch AA, Manjer J, Ferrari P, Riboli E, Bingham S, Engeset D, Lund E, Slimani N (2009) Use of food supplements in the European prospective investigation into cancer and nutrition calibration study. Europ J Clin Nutr 63(Suppl 4):S226-S238

Sun H, Brocato J, Costa M (2015) Oral chromium exposure and toxicity. Current Environm Health Rep 2:295-303
The Expert Group on Vitamins and Minerals (2003) Safe upper levels for vitamins and minerals. Food Standards Agency Publications, London

Tumir H, Bošnir J, Vedrina-Dragojević I, Dragun Z, Tomić S, Puntarić D, Jurak G (2010) Monitoring of metal and metalloid content in food supplements on the Croatian market. Food Control 21:885-889

Veprikova Z, Zachariasova M, Dzuman Z, Zachariasova A, Fenclova M, Slavikova P, Vaclavikova M, Mastovska K, Hengst D, Hajslova J (2015) Mycotoxins in plant-based food supplements: hidden health risk for consumers. J Agric Food Chem 63:6633-6643

Verkaik-Kloosterman J, McCann MT, Hoekstra J, Verhagen H (2012) Vitamins and minerals: issues associated with too low and too high population intakes. Food Nutr Res. https://doi.org/10.3402/ fnr.v56i0.5728

Verkaik-Kloosterman J, Seves SM, Ocké MC (2017) Vitamin D concentrations in fortified foods and dietary supplements intended for infants: implications for vitamin D intake. Food Chem 221:629-635

Wierzejska R, Jarosz M, Siuba M, Rambuszek M (2014) Assessing patients' attitudes towards food supplements. Rocz Panstw Zakl Hig 65:317-323

Yang Q, Liu T, Kuklina EV, Flanders WD, Hong Y, Gillespie C, Chang MH, Gwinn M, Dowling N, Khoury MJ, Hu FB (2011) Sodium and potassium intake and mortality among US adults: prospective data from the Third National Health and Nutrition Examination Survey. Arch Intern Med 171:1183-1191

Yetley EA (2007) Multivitamin and multimineral food supplements: definitions, characterization, bioavailability, and drug interactions. Am J Clin Nutr 85:269-276 